\title{
HEAVY METALS ACCUMULATION AND MACRONUTRIENTS IN THE LIVERS OF SOME FISH SPECIES OF BARDAWIL LAGOON AND THEIR HISTOLOGICAL CHANGES
}

\author{
Amal M. Yacoub and Amal M. Abdel Satar \\ National Institute of Oceanography and Fisheries, El Kanater El \\ Khairya Fish Research Station, Cairo, Egypt.
}

Key Words: Bardawil Lagoon, fish. liver. heavy metal. Histopatholgy.

\begin{abstract}
Gish samples of Solea vulgaris, Mugil cephalus, Liza ranada and 1 Sparus aurata were collected during November 2001 from El Telol location in Bardawil lagoon, north eastern of Egyptian Mediterranean coast. The study was conducted to assess the effect of the heavy metals (Fe. Mn. $\mathrm{Zn}$. Cu. Pb and $\mathrm{Cd}$ ) and the macronutrients $(\mathrm{Na}, \mathrm{K}, \mathrm{Ca}$, and $\mathrm{Mg}$ ) on livers tissues of the four fish species. The results showed that the concentrations of $\mathrm{Fe} . \mathrm{Mn}, \mathrm{Zn}, \mathrm{Cu} . \mathrm{Pb}$, and $\mathrm{Cd}$ in the livers of the four fish species ranged between 48.680-121.940. 1.270- 2.170. 15.220-32.570. 82.280-301.830. 1.100- 4.960 and $0.180-0.300 \mathrm{mg} / \mathrm{Kg}$ respectively. The concentrations of $\mathrm{Na}, \mathrm{K} . \mathrm{Ca}$ and $\mathrm{Mg}$ in the livers of the four species ranged between $1131.60-$ $1702.00,327.60-507.00 .74 .490-398.300$ and $72.180-170.590 \mathrm{mg} /$ $\mathrm{Kg}$ respectively. Microscopical examination of livers tissues of Solea vulgaris, Liza ramada. Mugil cephalus and Sparus caurala showed different degrees of injuries, including fatty degeneration, ballooning degeneration, accumulation of hemosiderin pigment and necrosis.
\end{abstract}

\section{INTRODUCTION}

Bardawil lagoon is a salt water lagoon in the northern coast of Sinai province of Egypt, with an average water spread area of about $1600 \mathrm{Km}^{2}$. Its average depth is $2.5 \mathrm{~m}$. It is connected to the Mediterranean Sea through two Boughases (Fig. 1). The lagoon is subjected to tidal effects, arid conditions and high evaporation. Yitzhak (1971) studied the cations and anions of water samples collected from three parts of the lagoon, also sediment was examined by X Rays. Siliem (1988 a and b) determined the major cations 
namely Sodium, Potassium, Calcium and Magnesium as well as the major anions namely sulphate and bromide, with their distribution and chlorinity ratios. The anions chlorinity ratios were higher in the lagoon than in normal seawater. Siliem (1989 a, b and c) studied some limnological characteristics of the lagoon with the distribution of nutrients and the enrichment ratio of the major cations and anions.

The importance of fisheries economy of Egypt depends mainly on the Egyptian lakes. So, it was necessary to make intensive studies on the environment of these lakes to evaluate their productivity with regard to their fish production. The General Authority for Fish Resources Development (2002) reported that production of fishes and crustaceans decreased in Lake Bardawil during the last decade as illustrated in Table (1). The production of the lagoon decreased to the minimum level in 1994.

Fishes often lie at the top of aquatic food chain and may accumulate large amounts of metals. These metals accumulate differently in fish organs (kidney, brain, muscles, gills, gonads and liver)(Van Hassel et al., 1980; Moriarty, 1984; Dallinger et al., 1987; Mason,1987; Barak and Mason, et al., 1990; Naqvi and Howel,1993; Abou Arab et al., 1995 ; Gomaa et al., 1995).

Some heavy metals such as $\mathrm{Zn}, \mathrm{Cu}, \mathrm{Mn}$ and $\mathrm{Fe}$ are essential for growth and well being of living organisms including man. However, they are likely to show toxic effects when organisms are exposed to levels higher than normally required. Other elements such as $\mathrm{Pb}$ and $\mathrm{Cd}$ are not essential for metabolic activities and exhibit toxic properties. At low concentrations. many heavy metals including $\mathrm{Hg}, \mathrm{Cd}, \mathrm{Pb}, \mathrm{As}$ and $\mathrm{Cu}$, inhibit photosynthesis and phytoplankton growth. Effects at higher trophic levels include delayed embryonic development, malformation and reduced growth of adult fishes, molluscs and crustaceans (FAO, 1992).

A knowledge of health condition of common fishes of Bardawil lagoon is necessary to explain the decline of fish production. The present study aimed to compare the effect of accumulation of six heavy metals $(\mathrm{Zn}, \mathrm{Cu}, \mathrm{Cd}, \mathrm{Pb}, \mathrm{Fe}$ and $\mathrm{Mn})$ and four macronutrients $(\mathrm{Mg}, \mathrm{Ca}, \mathrm{Na}$, and $\mathrm{K}$ ) on the liver tissue in four common fish species in Bardawil lagoon, namely .Solea vulgaris (Linnaeus), Mugil cephalus (Limnaeus), Liza ramada (Risso) and Sparus aurata (Linneaus). 


\section{MATERIAL AND METHODS}

\section{a- Collection of fish samples :}

Fish samples of Solea vulgaris, Mugil cephalus, Liza ramada and Sparus alrata were collected during November, 2001 from El Telol location in Bardawil lagoon. The length and weight of each specimen was recorded. Specimens were dissected and their livers were carefully removed and fixed in 10\% formalin for histological examination. other liver specimens were kept frozen for analysis of metals.

The weights of specimens ranged between 69.5- 139.6, 102.5138.2. 110- 168.8 and 115.4- $170 \mathrm{gm}$ for Solea vulgaris. Sparus aurla, Mugil cephalus and Liza ramada respectively.

\section{b- Method of metals analysis :}

Liver tissues of different fish species were dried in an oven at $105^{\circ} \mathrm{C}$ for about 24 hours, then ground to fine powder. A representative sample of $2 \mathrm{gm}$ dry weight of liver was taken from fish specimens. The samples were digested according to the method described by Goldberg et al. (1993) in which concentrated nitric and perchloric acid (AR grade) with ratio of $5 \mathrm{ml}+5 \mathrm{ml}$ were used in Teflon beakers on a hot plate, at $50^{\circ} \mathrm{C}$ for about 5 hours till complete decomposition of organic matter. The digested solutions were cooled to room temperature. filtered and diluted to a final volume of $50 \mathrm{ml}$ deionized distilled water. The concentration of Zinc. Copper. Cadmium, Lead, Iron. Manganese, Magnesium. Calciun. Sodium and Potassium were measured by (I. C.P.) Plasma 400. Results were expressed in $\mathrm{mg} / \mathrm{Kg}$ dry weight of liver tissue .

\section{c- Histological method:}

About five fishes were dissected from each species. Liver specimens were carefully removed and immediately fixed in $10 \%$ formalin, then delyydrated in ascending grades of alcohol.cleared in xylene. The fixed tissues were embedded in parafin wax, sectioned at 5 microns, stained with haematoxylin and eosin ( $H \& E)$ and examined microscopically. 


\section{RESULTS AND DISCUSSION}

The results indicated that iron concentrations in livers of the four fish species ranged from 48.680 to $121.940 \mathrm{mg} / \mathrm{Kg}$ dry weight (Table 2). The concentrations of iron were of the following order: Mugil cephalus < Solea vulgaris < Liza Ramada<Sparus aurta. U.S.recommended $0.5 \mathrm{gm}$ iron daily dietary allowance supplied by $100 \mathrm{gm}$ serving of fish muscle as cited by Adeyeye (1993a). The concentrations obtained in the present study were significantly higher than the allowed level in all fish species.

Manganese concentrations in the livers of the four fish species ranged from 1.270 to $2.170 \mathrm{mg} / \mathrm{Kg}$ dry weight ( Table 2). The concentrations of manganese were detected in the following order : Mugil cephalus < Sparus aurata < Liza ramada < Solea vulgaris.

Manganese functions as an essential constituent for bone structure, reproduction and normal functioning of the enzyme System (Fleck,1976). Manganese is toxic only when present in higher amount, but at low levels is considered essential as micronutrient (Sarkka et al., 1978).

Zinc concentrations in the livers of the present fish species ranged from 15.220 to $32.570 \mathrm{mg} / \mathrm{Kg}$ dry weight (Table2). The concentrations of zinc were recorded in the following order : Solea vulgaris < Mugil cephalus < Liza ramada < Sparus aurata. Zinc is an essential element and a common pollutant as well. Mining, smelting and sewage disposal are major sources of zinc pollution. It is taken up by fish directly from water especially by mucous and gills (Skidmore. 1964). Koli et al. (1978) reported that $\mathrm{Zn}$ concentrations in muscle tissue of fish species from non-polluted areas. were less than $1 \mathrm{ppm}$. In the present study. zinc levels in the four fish species in Bardawil lagoon were significantly higher than in non-polluted areas.

Copper concentrations in livers of the present fish species ranged from 82.280 to $301.830 \mathrm{mg} / \mathrm{Kg}$ dry weight (Table 2). They were found in the following order: Sparus aurala $<$ Mugil cephalus $<$ Solea vulgaris < Liza ramada. Copper is a fundamental micronutrient to all forms of life, in enzyme activity or random rearrangement of natural proteins (Bower, 1979).

National Health and Medical Research Councils, recommended that the Standard Concentration of copper for human consumpution is $30.0 \mathrm{mg} / \mathrm{Kg}$ (Bernard, 1982). The concentrations of copper in the studied fish species in Bardawil lagoon were higher 
than the Standard Concentrations. Gainey and Kenyom (1990) mentioned that exposure of tishes to sublethal concentrations of copper leading to decrease in cardiac activity and reduction in heart rate.Khallaf et al.(1998) indicated that liver accumulated higher amounts of copper and which may be due to its ability to retain copper. The concentrations of lead in the tivers of the four fish species ranged from 1.10 to $4.96 \mathrm{mg} / \mathrm{Kg}$ dry weight (Table2). They were present in the following order: Spartus curta $<$ Murgil cephalus $<$ Liza ramada $<$ Solea vulgaris.

USFDA (Food and Drug Administration) maximum permissible level for lead as cited by Adeyeye (1993b) is $2.0 \mathrm{mg} / \mathrm{Kg}$ in fish muscles. So, the present concentrations were higher than the maximum permissible level (MPL) in all tishes except Sparis curcuta . Lead is toxic even at low concentrations and has no known function in biochemical processes. It is known to inhibit active transport mechanisms, involving ATP, to depress cellular oxidation reduction reaction and to inhibit protein synthesis (Waldron and Stofen, 1974). The major source of lead is the use of leaded gasoline. The concentrations of cadmium in the livers of the present fish species ranged from 0.18 to $0.3 \mathrm{mg} / \mathrm{Kg}$ dry weight (Table 2). They were determined by the following order : Solea vulgaris < Liza ramacka < Mugil cephalus and Sparus aurata. Cadmium levels in the investigated fish livers were found to be lower than the permissible limit $(0.5 \mathrm{mg} / \mathrm{Kg})$ of National Academy of Science (1972). On the other hand, the recommendations of National Health and Medical Research Council in Australia (NHMRC), showed that the concentrations of $\mathrm{Cd}$ and $\mathrm{Pb}$ in the edible parts of fish should not exceed $2.0 \mathrm{mg} / \mathrm{Kg}$ (Bebbington et al.,1977). It is clear from the present study that. bioaccumulation of heavy metals in fish livers varied according to the fish species. Bryan and Uysal(1978) rported that, the feeding type and environmental conditions of the aquatic animals have an effect on their concentrations of elements. In general , animals take the metal directly from water or through their food chain. The levels of bioaccumulation of trace metals in various organs. of fish reflect the degree of water pollution in the aquatic environment in which such fish are living.

Portman (1972) indicated that the rate of accumulation of heavy metals in aquatic organisms is positively correlated to their concentrations in the marine environment. Because fish accumulate trace elements from their environment and can act as indicator of such metals in the environment, they are excellent organisms for the 


\section{8 \\ HEAVY METALS ACCUMULATION \\ IN THE LIVERS OF SOME FISH SPECIES OF BARDAWIL}

study of long term changes in the marine environment (Ghazaly, 1992).

The concentrations of macronutrients in livers of the present fishes ranged between 398.3-74.49, 170.59- 72.18, 1702-1131.6, $507-327.6 \mathrm{mg} / \mathrm{Kg}$ dry weight for $\mathrm{Ca}, \mathrm{Mg}, \mathrm{Na}$ and $\mathrm{K}$ (Table2). The maximum values of magnesium and sodium were detected in the livers of Solea vulgaris while the maximum values of calcium and potassium were detected in Sparus aurata. Abdel Satar and Shehata (2000) showed that sodium levels were in the range of 2497-4713 and $2579-4030 \mathrm{mg} / \mathrm{Kg}$ for the fish flesh of Oreochromis niloricus and Tilapia zillii respectively in River Nile. However, potassium levels were in the range of $3042-4249$ and $3042-4499 \mathrm{mg} / \mathrm{Kg}$ for $O$. niloricus and $T$. zillii respectively. Calcium levels were in the range of $419-1240$ and $469-1642 \mathrm{mg} / \mathrm{Kg}$ and magnesium concentrations ranged between $282.2-321.4$ and $2923-325.3 \mathrm{mg} / \mathrm{Kg}$. In comparison with results of Abdel-Satar and Shehata (2000), muscles of Oreochromis niloticus and Tilapia zillii were quite richer in macronutrients than livers of Solea vulgaris, Muggil cephalus, Liza ramada and Sparus currata in the present study.

Heavy metals pollution induce pathological changes in fishes, as the liver is the main detoxificating organ of the body and the integrator for biochemical and physiological functions. Also this organ carries out key functions in excretion of xenobiotics (Geneser. 1993).

The liver section of Solea vulgaris showed dilation and destruction of central vein. The hepatocytes showed fatty degeneration with vacuolar necrosis (Fig.2) and the blood cells were infiltrated within the hepatocytes (Fig. 3). Beside, hemolysis of blood cells appeared (Fig. 4).

The liver sections of Liza ramada contained enlarged nuclei (Fig. 5). Some hepatocytes contained eccentrically located nuclei and large fat vacuroles occupied the cytoplasm (fatty degeneration) (Fig. 6). It also showed accumulation of hemosiderin pigment as a result of destruction of erythrocytes (Fig. 7).

Alterations developed to include hemorrhagic lesions accompanid by accumulated hemosiderin pigment. Hemorrhage was abundant most probably due to the inflammation of tissue. The rapid and continued destruction of erythrocytes, breakdown of hemoglobin converted them into hemosiderin. The respiratory activity and iron metabolism of cells were damaged with anaemic anoxia. Large 
amounts of iron were absorped by the way of intestinal mucosa. This process was responsible for the abnormal accumulation of hemosiderin in the liver (Yacoub. 1994).

The histopathological changes in the liver of Solea mulgaris and Liza ramala were similar to those observed in other fishes due to chemical toxicant under laboratory conditions. Sastry and Gupta (1979) have reported vacuolation. degeneration of nuclei. accumulation of lipid and focal necrosis in liver cells of Heteropneustes fossilis subjected to sublethal concentration of cadmium chloride. They attributed the fatty accumulation to an increased mobilization and transport of fat to the liver. Also. the liver of Clarias gariepinus contained fatty degeneration. severe hemorrhage and accumulation of hemosiderin in River Nile water polluted with lead in the area of Greater Cairo (Yacoub. 1999).

Laboratory studies have shown that hemosiderin (ferric iron) concentration increased temporaliy in fish exposed to petroleumcontaminated sediment and also sediment originating from the vicinty of a pulp and paper mill (Khan and Nag. 1993). Some studies also revealed a link between hepatic lesions and the concentration of hemosiderin (Khan, 1998 and 1999). These results support the view proposed by other studies that hemosiderin concentration can represent a useful tool for monitoring fish health (Bucke ef cal. 1984. 1992; Wolke et al. 1985 and Peters et al. 1987).

Liver tissue of Mugil cephalus demonstrated ballooning degeneration (Fig. 8). The hepatocytes were degenerated and the central vein dilated and invaded with hemolysed blood cells (Fig.9). The hepatic vein appeared congested with blood and the hemoglobin of some erythrocytes converted intu hemosiderin (Fig.10). The hepatocytes showed degeneration, necrosis and infiltration of blood cells (Fig.11).

The liver of Sparus aurata contained a diffuse arrangement of pancreatic tissue (Fig.14 and 15). Section of liver of Sparus carta exhibited degeneration and necrosis of hepatocytes (Figs.12 and 13). A large necrotic area was occupied by debris of hepatocytes and blood cells. Stagnant blood and degenerated pancreatic acini appeared within the hepatic tissue (Figs.14 and 15). Sparus aurata exhibited the most progressive pathological changes among the four examined fish species of Bardawil lagoon. The present study suggests a strong link between heavy metals and lesions in the liver. Sorensen ef al.(1980) cited that heavy metals in Elbe water that might cause liver damage, are chiefly responsible for necrotic processes in fish liver. 


\section{HEAVY METALS ACCUMULATION \\ IN THE LIVERS OF SOME FISH SPECIES OF BARDAWIL}

Sastry and Gupta (1978) studied the effect of lead nitrate on the teolest fish Channa punctatus. They reported that the structural damage in the liver may be correlated with alterations in enzyme activities. There was an inhibition in alkaline phosphatase activity indicating that the transphosphorylation reactions were inhibited. There is a slight insignificant increase in acid phosphatase activity. which can be correlated with the degeneration of hepatocytes. Lumlertdacha el al.(1995) noticed areas of vacuolated hepatocytes in channel catfish. The vacuoles contain lipid. which is suggestive of impaired lipid metabolism.

Similar results were obtained by Ghosh and Chakarbati(1993) after treatment of Heleropneustes fossilis by sublethal concentrations of cadmium and histological changes were exanined in liver. Cytoplasmic vacuolations, eccentric nucleus and rupture of cell membranes of hepatocytes were the most conspicuous changes in liver.

Also, similar histopathological lesions were observed in liver of fish under the effect of different toxicants. Degenerative and inflammatory lesions of liver of brown trout (Salmo irulla) and rainbow trout (Oncorhynchus mykiss) were observed after a long term exposure to diluted sewage plant effluent (Schmidt et al.,1999) and vacoulizations and necrosis of hepatocytes of rainbow trout (Oncorhynchus mykiss) after feeding with diets rich in oxidized lipids (Daskalov ef al.,2000)

In conclusion. water level in Bardawil lagoon is low and constant. So, concentrations of heavy metals increased gradually through the years. The accumulations of heavy metals caused different degrees of injuries in the livers of the investigated fish species.

\section{REFERENCES}

Abdel Satar, A. M. and Shehata, M. B. (2000). Heavy metals accumulation and macronutrient content in the flesh of two edible fish inhabiting the River Nile, Egypt. I.Egypt.Acad.Environ.Develop.. I(1): 99-111.

Abou Arab, A. A. K. : Ayesh. A. M. ; Amra, H. A. and Naguib, K. (1995). Some pesticides and heavy metals contents of imported fish (Sardin and Mackerel) in Egyptian markets. J. Agric. Sc., Mansoura Univ., 20(11): 4735- 4746. 
Adeyeye, E. I.(1993a). Trace heavy metals distribution in Illisha afficina fish organs and tissue 1: Chromium. Zinc. Copper. Iron and Cobalt. Pak. J. Sci. Res., 36: 333- 337.

Adeyeye. E. I. (I993b). Trace heavy metals distribution in Illisha africana (Block) fish organs and tissue 2: Lead and Cadmium. Ghana J. Chem., l: 377- 384.

Anonymous. (2002). Fisl production in the Egyptian lakes. General Authority for Fish Resources Development.

Barak, N. A. E. : Mason, C. F. (1990). Mercury, cadmium and lead in eels and roach. The effects of size. season and locality on metal concentrations in flesh and liver. Science of Total Environment. 92:249-256

Bebbington. G. N. : Mackey, N. J. ; Chvoike, R. ; William, R. I. : Dunn. A. : Auty, E. H. (1977). Heavy metals(selenium and arsenic) in nine species of Australian Commercial Fish. Aust. J. Mar. Freshwater Res., 28:277- 280.

Bernard, M. (1982). Levels of trace metals in the Mediterranean. VI Journee Etud. Pollutions. Cannes. GIESM1982.

Bower, J. J. M. (1979). Environmental chemistry of the elements. Academic press. London.

Bryan, G. W. and Uysal, H. (1978) Heavy metals in the burrowing bivalve Scorbicularia plana from theTamar Estuary in relation to environmental levels. Cited from Uysal. H. (1978). Accumulation and distribution of heavy metals in some marine organisms in the Bay of Izmir and Aegean sea. IV Journees Etud., Pollution Antalya. C.I.E.S.H.

Bucke, D. ; Watermann, B. ; and Feist, S. (1984). Histological variations of hepato-splenic organs from the North Sea dab, Limanda limanda L.J.Fish. Dis., 7: 255- 268

Bucke, D. ; Vethaak, A. D. and Long, T. (1992). Quantitative assessment of melanomacrophage centers ( $M$ M Cs) in dab (Limanda limanda) along a pollution transect in the German Bight. Mar. Ecol. Prog. Series, 91: 193- 196. 
412 HEAVY METALS ACCUMULATION IN THE LIVERS OF SOME FISH SPECIES OF BARDAWIL

Dallinger, R. ; Prosi, F. ; Segner, H. and Back, H. (1987). Contaminated food and uptake of heavy metals by fish : a review and proposal for further research. Oecologia (Berlin), 37: 9]- 98.

Daskalov, H. ; Robertson, P. A. W. and Austin, B. (2000). Influence of oxidized lipids in diets on the development of rainbow trout fry syndrome. J. Fish Disease, 23: 7- 14

F.A.O, (1992). Committee for Inland Fisheries of Africa. Report of the third assessing of the Working Party on Pollution and Fisheries. Accra, Ghana,25-29 November 1991. F.A.O. Fisheries Report. No. 471.

Fleck, H. (1976). Introduction to Nutrition. $3^{\text {rd }}$ edn., Mac Millan Publishing Co., Inc., New York, 552pp.

Gainy, L. F. and Kenyom, J. R. (1990). The effects of reserpine on copper induced cardiac inhibition in Mytillus edulis. COMP. Biochem. Physiol., 95C(2) :177- 179:

Geneser, F. (1993). Histologica. Editorial Medica Panamericana, 768. Ghazaly, K. S. (1992). A comparative study of trace element accumulation in tissues of the teleost Tilapia zillii from contaminated and clean areas. Bull. Nat. Inst. Oceanogr. Fish., A.R.E.. 18:33- 41.

Ghosh, A. R. and Chakrabati, P. (1993). Histopathological and histochemical changes in liver. pancreas and kidney of the freshwater fish. Hereropneustes fossilis. (Block) exposed 10 cadmium. Environ. Ecol.. 7I(1): 185- 188.

Goldberg, E. D. ; Koide. M. ; Hodge, V. ; Flegal, A. R. and Martin. J. (1993). U. S. mussel watch : 1977- 1978 results on trace metals and radionuclides. Estuar. Coastal Shelf Sci.. 16: 6993.

Gomaa, M. N. E. ; Abou Arab, A. A. K. ; Badawy, A. and Naguib, K. (1995). Distribution pattern of some heavy metals in Egyptian fish organs. Food Chemistry, 53: 385- 389. 
Khallaf, E. A. ; Galal, M. and Authman. M. (1998). Assessment of heavy metals pollution and their effects on Oreochromis niloticus in aquatic drainage canals. J.Egypt. Ger. Soc. Zool.. 26(B) : 39- 74 .

Khan, R. A. (1998). Influence of petroleum at a refinery terminal on feral winter flounder. Pleuronectes americanus. Bull. Environ. Contam. Toxicol., 61: 770- 777.

Khan, R. A. (1999). Study of Pearl dace (Margaricus margariala) inhabiting a stillwater pond contaminated with diesel fuel. Bull. Environ. Contam. Toxicol., 62 : 638- 645.

Khan, R. A. and Nag, K.(1993). Estimation of hemosiderosis in seabirds and fish exposed to petroleum. Bull. Environ. Contan. Toxicol.. 50:125-131.

Koli, A. K. ; Sandhu, S. S. ; Canty, W. T. ; Felix, K. L. ; Reed. R. G. and Whitemore. R. (1978). Trace metals in some fish species of south Carolina. Bull. Environ. Contam. Toxicol., 20(3): 328- 331 .

Lumlertdacha, S. ; Lovell, R. T. ; Shelby, R. A. ; Lenz. S. D. and Kampainen, B. W. (1995). Growth hematology and histopathology of Channel catfish, Icralurus punciatus fed toxins from Fusarium moniliforme. Aquacult.. I(1)3: 201218.

Mason, C. F. (1987). A survey of mercury, lead and cadmium in muscle of British freshwater fish. Chemosphere. 16(4): 901906.

Moriarty. F. (1984). Persistent contaminants. compartmental models and concentration along food chains. Ecological Bull.. 36: 35- 45 .

Naqvi, S. M. and Howell, R. D. (1993). Cadmium and lead uptake by red swamp cryfish (Procambarus clarkii) of Louisiana. Bull. Environ. Contam. Toxicol., 51: 296- 302. 
National Academy of Science (1972). Section 3-Freshwater Aquatic Life and Wildlife, and section 4 - Marine Aquatic Life and Wildlife. Pages : 106- 296 in Water Quality Criteria. Ecological Research Series. EPA - R3 - 37 - 033. NAS. Washington.

Peters, N. ; Kohler. A. and Kranz, H. (1987). Liver pathology in fishes from the lower Elbe as a consequence of pollution. Dis. Aquat. Org.. 2: 87- 97.

Portman. J. E. (1972). The levels of certain metals from coastal waters around England and Wales. J. Aquacult.. $I: 91-96$.

Sarkka, J. ; Hatulla. M. L. ; Pasivirta, J. and Janatuinem. J. (1978). Mercury and chlorinated hydrocarbons in food chain of lake Paynma, Finland. Holarctic Ecol., l: 326- 332.

Sastry, K. V. and Gupta. P. K. (1978). Histopathological and enzymological studies on the effect of chronic lead nitrate intoxication in the digestive systen of a freshwater teleost. Channa punctatus. Environ. Res., 17: 472- 479.

Sastry, K. V. and Gupta, P. K. (1979). The effect of cadmium on the digestive system of the teleost fish. Hereropneustes fossilis: Environ. Res.. 19: 221- 230.

Schmidt, H. ; Bernet. D. : Wahli. T. ; Meier. W. and Burkhardt Holm, P. (1999). Active biomonitoring with brown trout and rainbow trout in diluted sewage plant effluents. J. Fish Biology, 54: 585- 596.

Siliem, T. A. E. (1988 a). Chemical conditions in Bardawil lagoon : 1- The major cations. Bull. Inst. Oceanogr. \& Fish.. ARE. 14: $123-140$.

Siliem, T. A. E. (1988 b). Chemical conditions in Bardawil lagoon : 2- The major anions. Bull. Inst. Oceanogr. \& Fish.. ARE, $14: 141-157$. 
Siliem, T. A. E. (1989 a). Chemical conditions in Bardawil lagoon. 3Some limnological studies. Bull. Nat. Inst. Oceanogr. \& Fish., ARE, 15: 21-33.

Siliem, T. A. E. (1989 b). Chemical conditions in Bardawil lagoon. 4Nutrient salts. Bull. Nat. Inst. Oceanogr. \& Fish., ARE. 15(2) : 217-227.

Siliem, T. A. E. (1989 c). Chemical conditions in Bardawil lagoon. 5Enrichment ratio of the major cations and anions. Bull. Nat. Inst. Oceanogr. \& Fish.. ARE, 15(2): 229- 23 b.

Skidmore, J. 3. (1964). Toxicity of zinc campounds to aquatic animals, with special references to fish. Quart. Rev.Biol.. $39(3)$ : 227- 248 .

Sorensen, E. M. B. ; Ramirez - Mitchell, R. ; Harlan. C. W. and Bell. J. S. (1980). Cytological changes in the fish liver following chronic, environmental arsenic exposure. Bull. Environ. Contam. Toxicol., 25 : 93-99.

Van Hassel, J. H. ; Ney, J. J. and Garling. D. L. (1980). Heavy metals in a stream ecosystem at sites near highways. Trans. An. Fish. Soc., 109: 636-643.

Waldron, H. A. and Stofen, S. (1974). Sub-clinical lead poisoning. Academic Press, New York, 1- 224.

Woke, R. E. ; Murchelano, R. A. : Dickstein, C. J. and George. C. I. (1985). Preliminary evaluation of the use of macrophage aggregates (MA) as fish health monitors. Bull. Environ. Contam. Toxicol., 35: 222- 227.

Yacoub, A. M. (1994). Effect of pollution in lake Quarun on Solea vulgaris. M. Sc. Thesis, Ain Shams Univ., Girls College. Zoology Dep.. 205. 


\section{6 \\ HEAVY METALS ACCUMULATION IN THE LIVERS OF SOME FISH SPECIES OF BARDAWIL}

Yacoub, A. M. (1999). Effect of pollution in different localities of River Nile on Clarias lazera (gariepinus). Ph. D.Thesis. Ain Shams Univ., Faculty of Sciece, Zoology Dep., 347.

Yitzhak, L. (1971). Anomalies of Calcium and Sulphate in the Bardawil Lagoon North Sinai. Limnol. \& Oceanogr.. 16(6):983-987. 


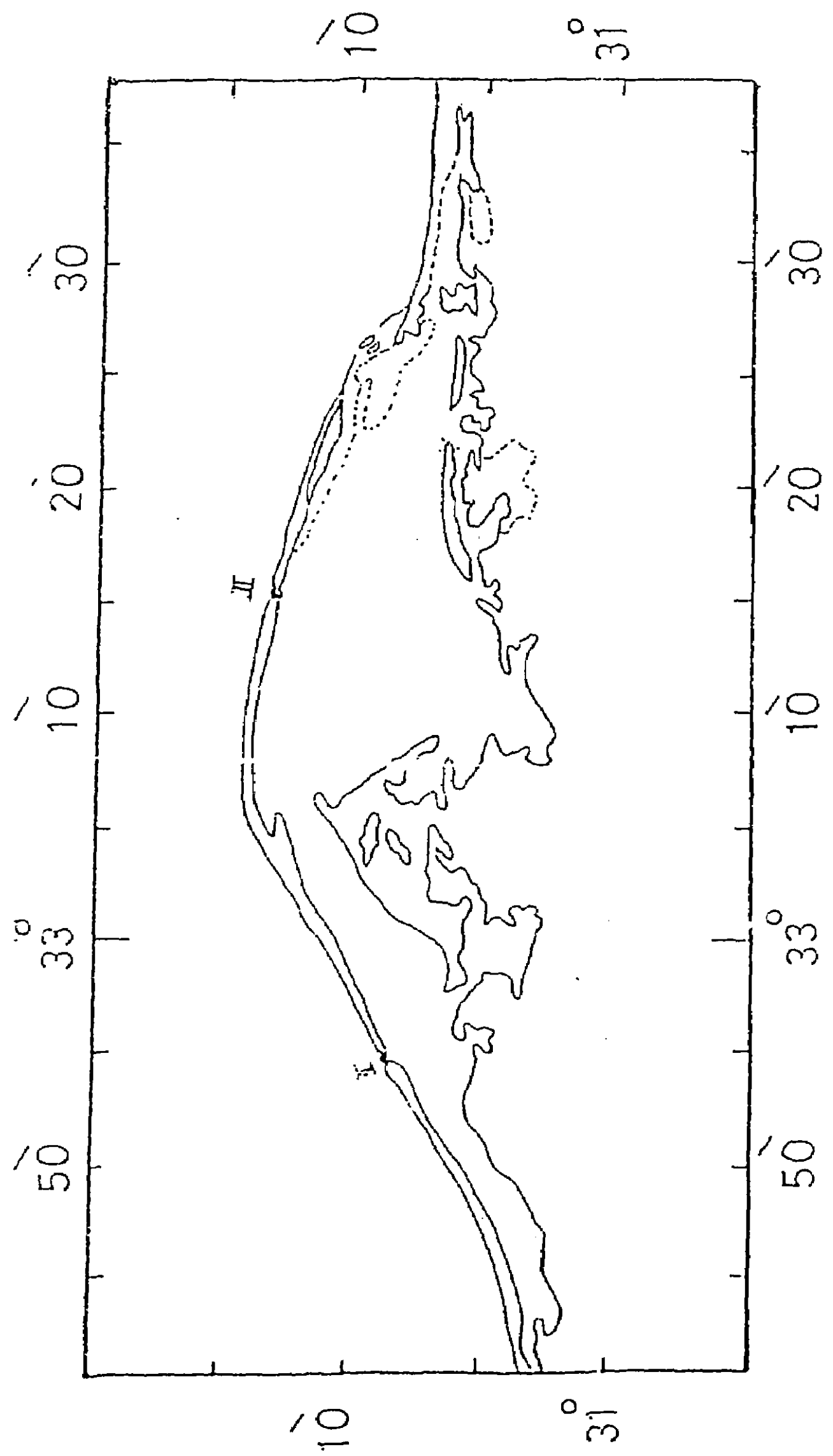

(Fig. 1) : Map of Bardawil lagoon illustrating the connection with the Mediterranean Sea through Boughases ( $\mathrm{l}$ and II). 
(Table 1) Production of Bardawil lagoon in the period from 1991 to 2001 .

\begin{tabular}{|c|c|}
\hline Years & Total production in tons \\
\hline 1991 & 2988 \\
\hline 1992 & 1838 \\
\hline 1993 & 2205 \\
\hline 1994 & 1575 \\
\hline 1995 & 2172 \\
\hline 1996 & 1627 \\
\hline 1997 & 2230 \\
\hline 1998 & [937 \\
\hline 1999 & 3890 \\
\hline 2000 & 3300 \\
\hline 2001 & 3146 \\
\hline
\end{tabular}




\section{IN THE LIVERS OF SOME FISH SPECIES OF BARDAWIL'}

(Table 2) The concentrations (mg / Kg dry weight) of heavy metals and macronutrients in the liver of the studied fish species in Bardawil lagoon.

\begin{tabular}{|c|c|c|c|c|}
\hline Metal & $\begin{array}{c}\text { Solea } \\
\text { vulgaris }\end{array}$ & $\begin{array}{c}\text { Mugil } \\
\text { cephalus }\end{array}$ & $\begin{array}{c}\text { Liza } \\
\text { ramada }\end{array}$ & $\begin{array}{l}\text { Sparms: } \\
\text { aurala }\end{array}$ \\
\hline $\mathrm{Fe}$ & 72.95 & 48.68 & 97.15 & 121.94 \\
\hline $\mathrm{Mn}$ & 2.17 & 1.27 & 1.71 & 1.48 \\
\hline $\mathrm{Zn}$ & 15.22 & 18.07 & 30.80 & 32.57 \\
\hline $\mathrm{Cu}$ & 184.25 & 147.76 & 301.83 & 82.28 \\
\hline $\mathrm{Pb}$ & 4.96 & 2.32 & 3.13 & 1.10 \\
\hline $\mathrm{Cd}$ & 0.18 & 0.30 & 0.28 & 0.30 \\
\hline $\mathrm{Ca}$ & 89.70 & 74.49 & 112.84 & 398.30 \\
\hline $\mathrm{Mg}$ & 170.59 & 72.18 & 133.00 & 94.64 \\
\hline $\mathrm{Na}$ & 1702.00 & 1131.60 & 1177.60 & 1288.00 \\
\hline " K & 335.40 & 358.80 & 327.60 & 507.00 \\
\hline
\end{tabular}




\section{EXPLANATION OF FIGURES}

(Fig. 2) : Section of liver of Solea vulgaris fish obtained from Bardawil lagoon. showing dilation and destruction of central vein (CV).

$\mathrm{X} 400$

(Fig. 3) : Section of liver of Solect vulgaris tish obtained from Bardawil lagoon. showing fatty degeneration of hepatocytes (H) and infiltration of erythrocytes (E).

$X+00$

(Fig. 4) : Section of liver of Solea vulgerris fish obtained from Bardawil lagoon, showing hemolysis of some erythrocytes and stagnant blood (B).

$\mathrm{X} 400$

(Fig. 5) : Section of liver of Liza rumada fish obtained from Bardawil lagoon, showing degeneration of hepatocytes $(\mathrm{H})$ and enlargement of some nuclei.

$\mathrm{X} 400$

(Fig. 6) : Section of liver of Lizar ramader fish obtained from Bardawil lagoon. showing dilation of central vein (CV) and fatty degeneration of hepatocytes $(H)$.

$\mathrm{X} 400$

(Fig. 7) : Section of liver of Liza ramada fish obtained from Bardawil lagoon, showing accumulation of hemosiderin pigment $(\mathrm{He})$.

$\mathrm{X} 400$

(Fig. 8) : Section of liver of Mugil cephalus fish obtained from Bardawil lagoon, showing ballooning (Ba).

$\mathrm{X} 400$

(Fig. 9) : Section of liver of Mugil cephilus tish obtained from Bardawil lagoon, showing dilation of central vein and hemolysis of erythrocytes (E).

$\mathrm{X} 400$

(Fig. 10) : Section of liver of Mugil cephalus fish obtained from Bardawil lagoon, showing congestion with blood and accumulations of hemosiderin (He) inside a hepatic vein.

$\mathrm{X} 400$

(Fig. 11) : Section of liver of Mugil cephallas fish obtained from Bardawil lagoon, showing necrotic area (NA) occupied by: blood cells. Notice infiltration of blood cells $(B C)$ within degenerated hepatocytes.

$\mathrm{X} 400$

(Fig. 12) : Section of liver of Sparus aurara fish obtained from Bardawil lagoon, showing lucent necrotic area (NA).X400

(Fig. 13) : Section of liver of Sparus aurata fish obtained from Bardawil lagoon, showing severe necrosis. Notice large necrotic area occupied by blood cells $(B C)$ and debris of hepatocytes.

$\mathrm{X} 400$ 


\section{IN THE LIVERS OF SOME FISH SPECIES OF BARDAWIL}

(Fig. 14) : Section of liver of Sparus aurata fish obtained from Bardawil lagoon, showing stagnant blood (B). Notice diffused arrangement of pancreatic acini within hepatic tissue.

$\mathrm{X} 100$

(Fig. 15) : Section of liver of Sparus aurata fish obtained from Bardawil lagoon. showing degeneration of pancreatic $\operatorname{acini}(\mathrm{PA})$.

$\mathrm{X} 400$ 


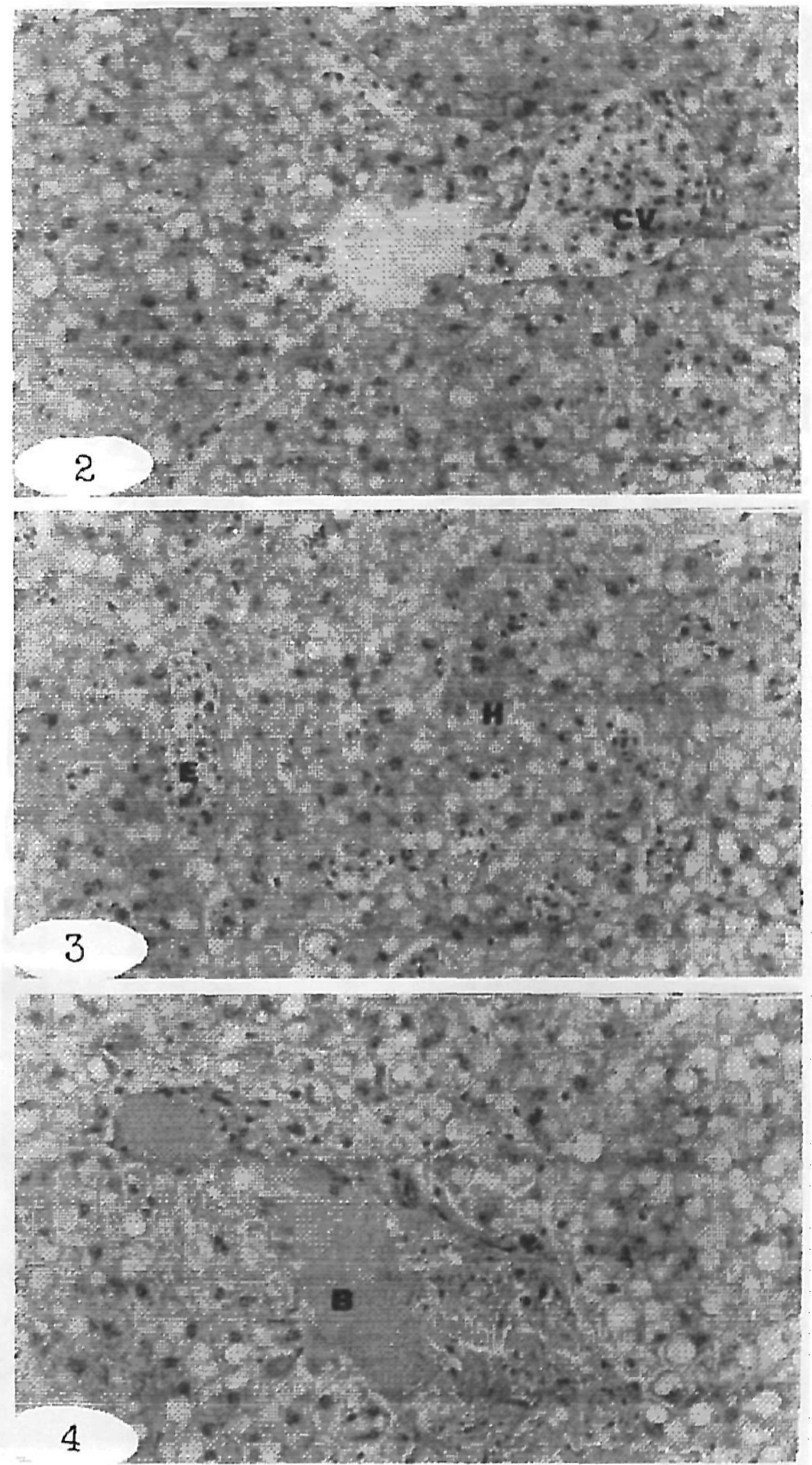




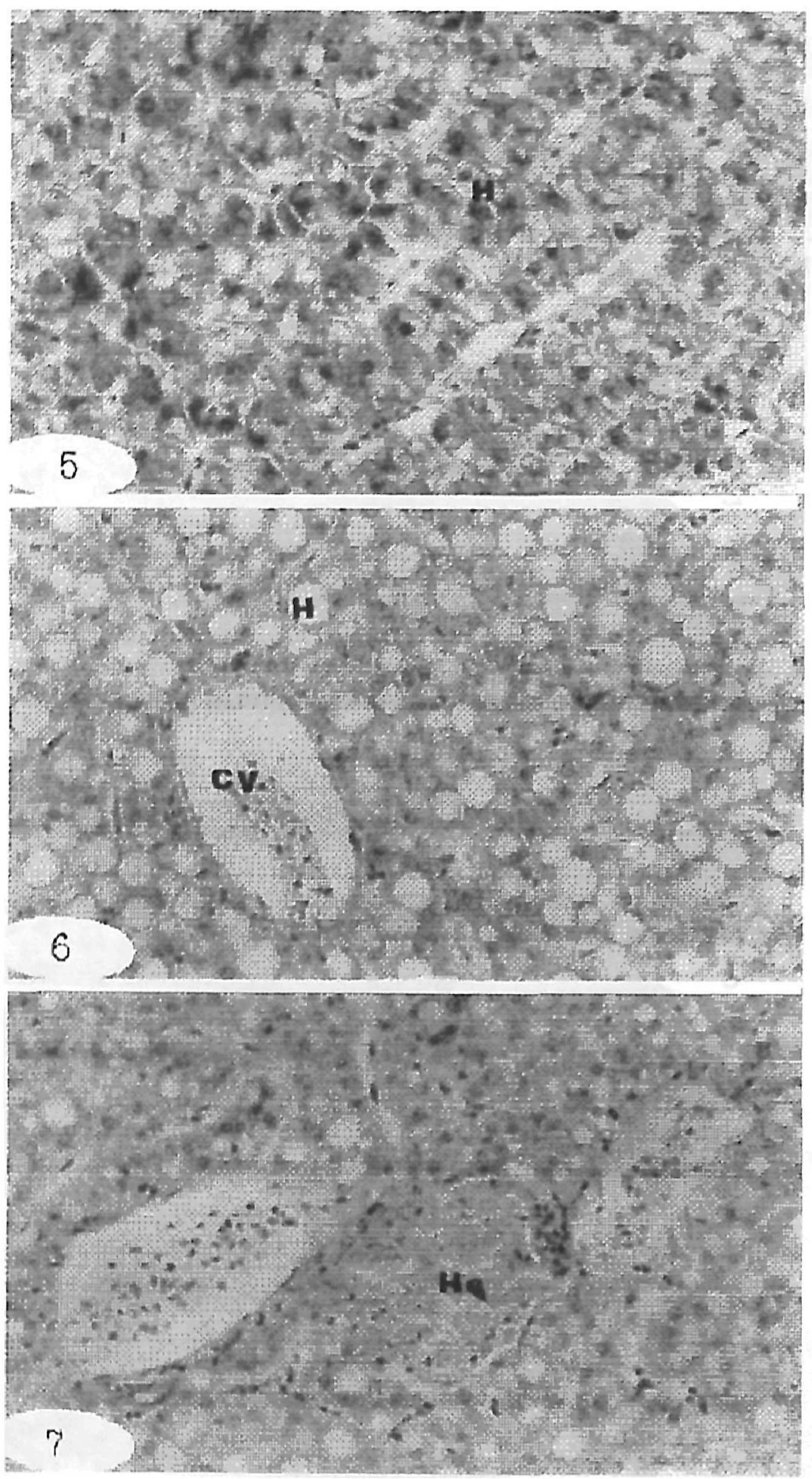



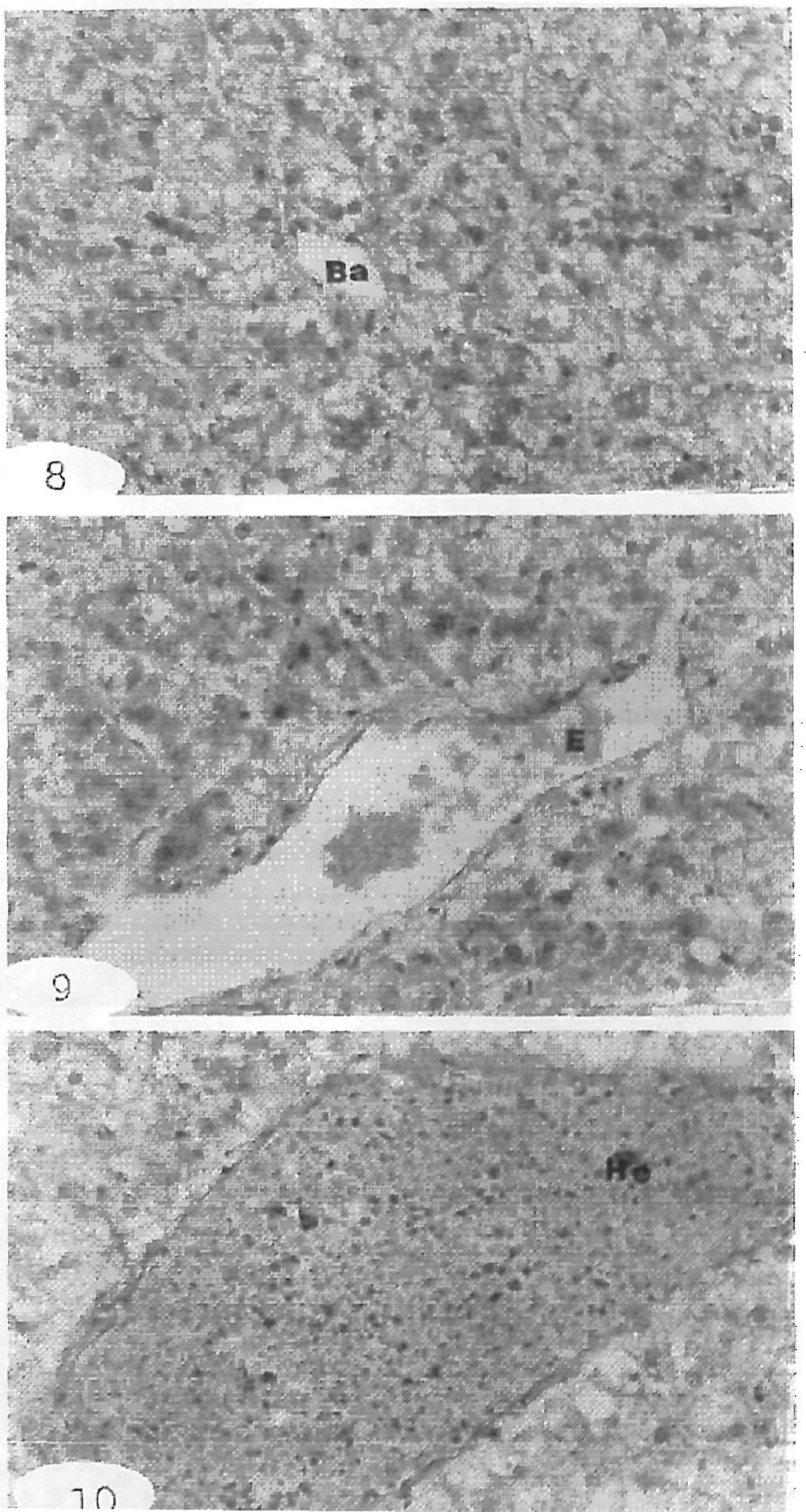

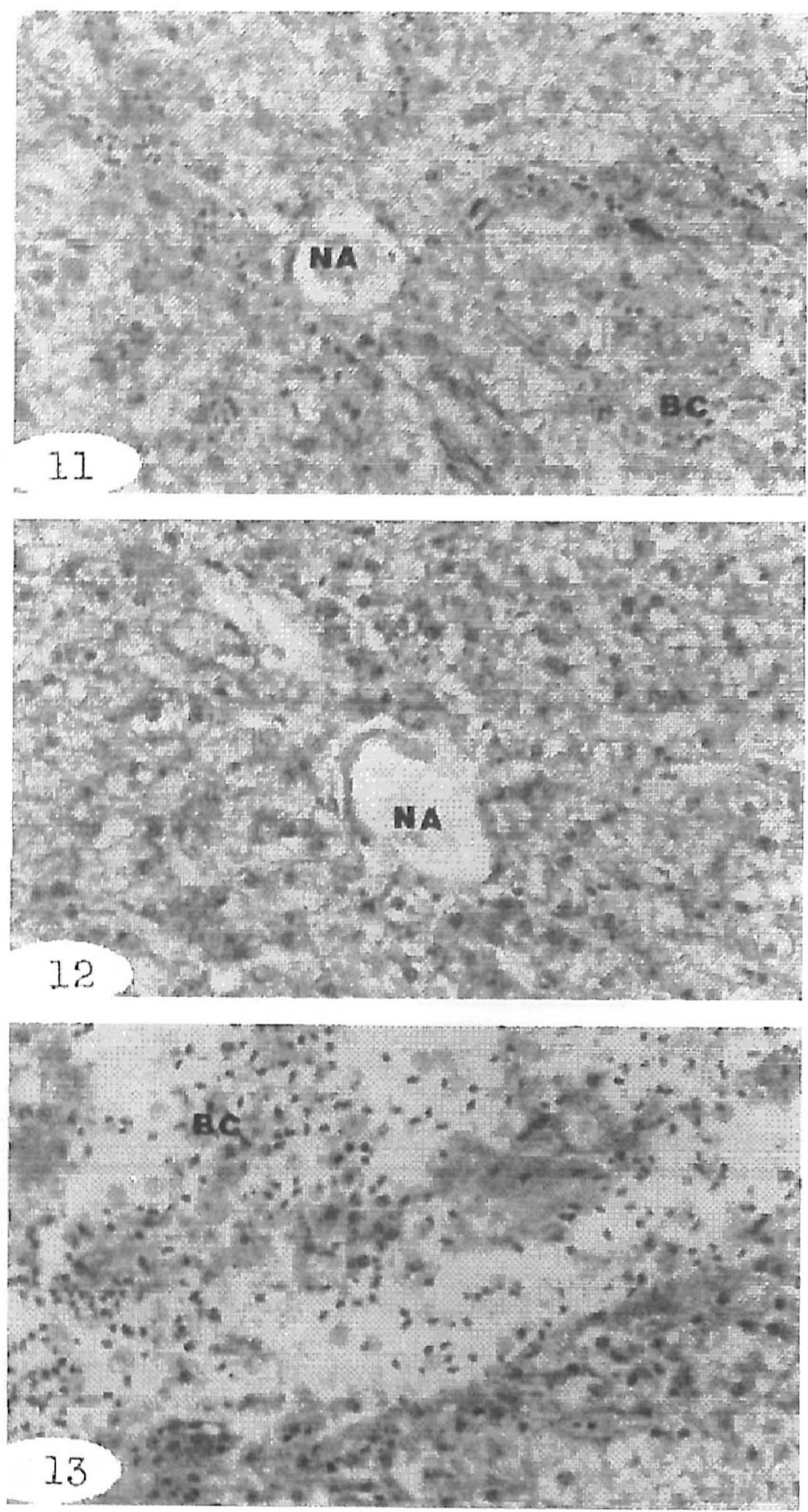


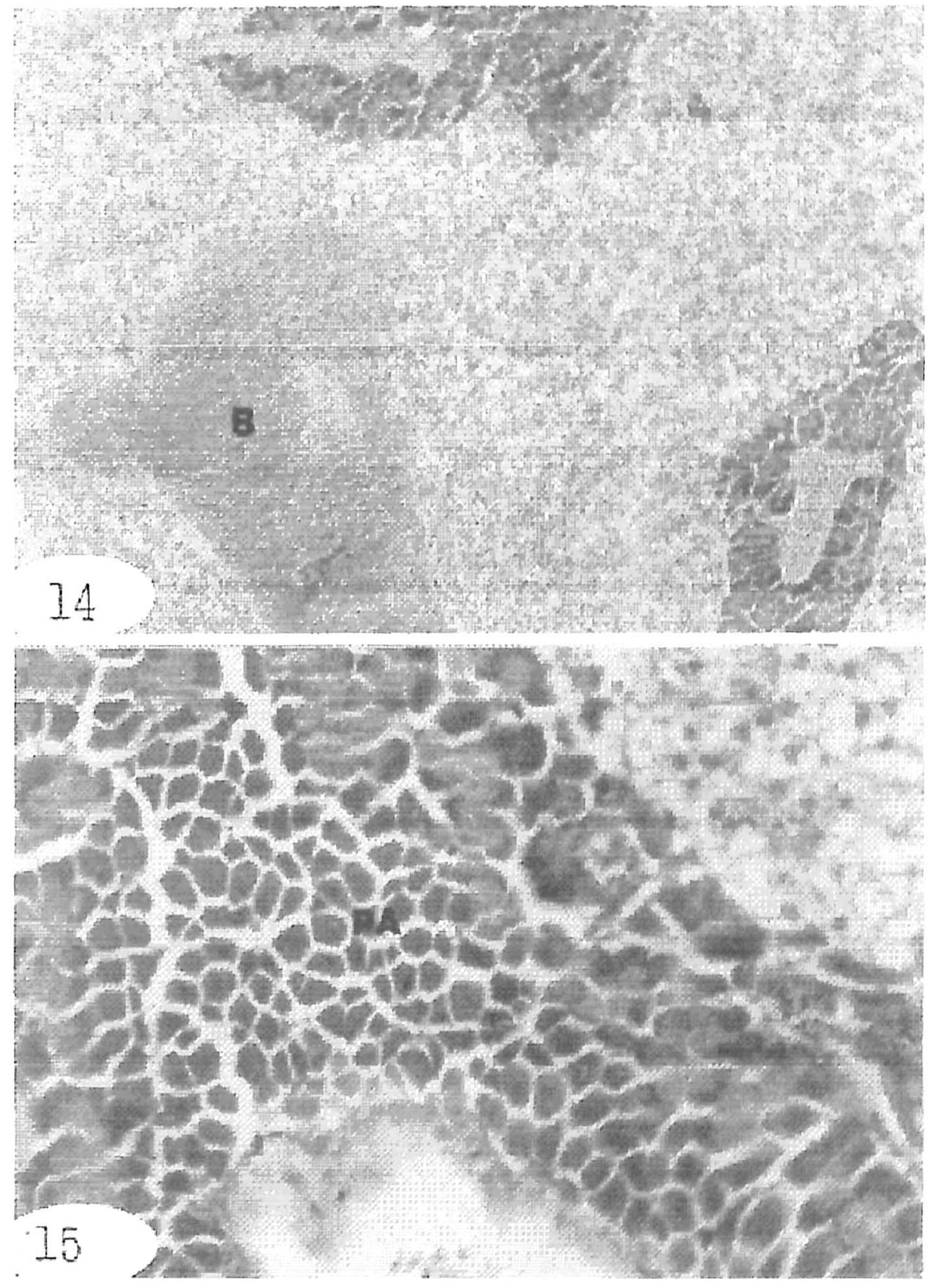

